\title{
Direct decomposition of methane over Ni catalyst supported in magnesium aluminate
}

\author{
Giselle D.B. Nuernberg ${ }^{\mathrm{a}}$, Edson L. Foletto ${ }^{\mathrm{b}, *}$, Carlos E.M. Campos ${ }^{\mathrm{c}}$, Humberto V. Fajardo ${ }^{\mathrm{d}}$, \\ Neftalí L.V. Carreño ${ }^{\mathrm{e}}$, Luiz F.D. Probst ${ }^{\mathrm{a}}$ \\ a Department of Chemistry, Federal University of Santa Catarina, 88040-900 Florianópolis, Brazil \\ ${ }^{\mathrm{b}}$ Department of Chemical Engineering, Federal University of Santa Maria, 97150-900 Santa Maria, Brazil \\ c Department of Physical, Federal University of Santa Catarina, 88040-900 Florianópolis, Brazil \\ d Department of Chemistry, Federal University of Ouro Preto, 35400-000 Ouro Preto, Brazil \\ e Technology Development Center, Federal University of Pelotas, 96010-900 Pelotas, Brazil
}

\section{A R T I C L E I N F O}

\section{Article history:}

Received 13 December 2011

Received in revised form 11 February 2012

Accepted 13 February 2012

Available online 21 February 2012

\section{Keywords:}

Methane decomposition

Magnesium aluminate

$\mathrm{MgAl}_{2} \mathrm{O}_{4}$

Synthesis

\begin{abstract}
A B S T R A C T
In this paper, the results obtained in the methane decomposition reaction promoted by a Ni catalyst supported on $\mathrm{MgAl}_{2} \mathrm{O}_{4}$ spinel are presented. The textural properties of the catalyst were investigated by $\mathrm{X}$-ray diffraction (XRD), $\mathrm{N}_{2}$ adsorption/desorption isotherms (BET and BJH methods), thermogravimetric (TGA) and temperature-programmed reduction (TPR) analysis. The influence of the operating conditions employed on the methane decomposition was studied. According to the results, it was found that a $\mathrm{N}_{2}: \mathrm{CH}_{4}$ molar ratio of $7: 1$ and catalyst reduction temperature of $700^{\circ} \mathrm{C} / 1 \mathrm{~h}$ were the best conditions for methane decomposition. In addition, in the methane decomposition over $\mathrm{Ni} / \mathrm{MgAl}_{2} \mathrm{O}_{4}$, multiwall carbon nanotubes were formed.
\end{abstract}

(c) 2012 Elsevier B.V. All rights reserved.

\section{Introduction}

Methane decomposition is a moderately endothermic reaction and, in general, only hydrogen is detected as the gaseous product. This process has been receiving increasing attention as an alternative route for the production of $\mathrm{CO} / \mathrm{CO}_{2}$-free hydrogen [1,2]. Unlike the conventional methods of hydrogen production from natural gas, i.e., methane steam reforming and methane partial oxidation, which produce a mixture of hydrogen and carbon oxides, the catalytic cracking produces hydrogen and solid carbon, thereby eliminating the necessity for the separation of hydrogen from the other gaseous products. This significantly simplifies the process, reduces overall $\mathrm{CO}_{2}$ emissions and makes the method particularly attractive for fuel cell applications, where hydrogen is the preferred fuel $[3,4]$. In addition, the decomposition of methane also results in the generation of a very important by product, nanocarbon materials (carbon nanotubes and nanofibers), that have been gaining considerable attention due to their excellent properties and potential applications [3-5].

Concerning the catalysts for the decomposition of methane, it is well known that supported $\mathrm{Ni}$ is one of the most effective

\footnotetext{
* Corresponding author. Tel.: +55 553220 8448; fax: +55 5532208030

E-mail address: efoletto@gmail.com (E.L. Foletto).
}

catalysts $[1,6]$. This metal has been supported over different materials $\left(\mathrm{MgO}, \mathrm{Al}_{2} \mathrm{O}_{3}, \mathrm{SiO}_{2}, \mathrm{TiO}_{2}, \mathrm{ZrO}_{2}, \mathrm{MgO} \cdot \mathrm{SiO}_{2}, \mathrm{H}^{+}-\mathrm{ZSM}-5\right.$, USY, MCM-22, MCM-41, NiCuAl, $\mathrm{LaNiO}_{3}$ ) and the effect these supports in the decomposition methane reaction has been examined [7-13].

Magnesium aluminate spinel, $\mathrm{MgAl}_{2} \mathrm{O}_{4}$, is an important ceramic and refractory material with several applications in many industries due to its properties, such as high melting point, low thermal expansion, high resistance to chemical attack, good mechanical strength, low dielectric constant and excellent optical properties [14-17]. However, the use of this material as a support for metallic catalysts is a relatively new application that has provided good results due to some of its attractive properties, such as low acidity, hydrophobic character, high thermal resistance and good interaction with the metallic phase, which are of interest for catalytic purposes [18-20]. We have recently shown that the magnesium aluminate spinel $\left(\mathrm{MgAl}_{2} \mathrm{O}_{4}\right)$ could be used as support of metals for the hydrogen production by direct decomposition of methane [21]. However, the use of this material as metal support for this specific reaction is scarce in the literature.

In the present work, the performance of $\mathrm{Ni}$ catalyst supported on $\mathrm{MgAl}_{2} \mathrm{O}_{4}$ was investigated in direct decomposition of methane. The influence of the operating conditions $\mathrm{N}_{2}: \mathrm{CH}_{4}$ molar ratio and catalyst reduction temperature employed on the methane decomposition was investigated. In addition, structure of carbons formed by the reaction was analyzed. 


\section{Experimental}

\subsection{Catalyst preparation}

The $\mathrm{MgAl}_{2} \mathrm{O}_{4}$ support was prepared as described by Foletto et al. [19]. In the preparation of the precursor, the following reactants were utilized: aluminum isopropoxide $\left[\left(\mathrm{CH}_{3}\right)_{2} \mathrm{CHO}\right]_{3} \mathrm{Al}$ and magnesium ethoxide $\left(\mathrm{C}_{2} \mathrm{H}_{5} \mathrm{O}\right)_{2} \mathrm{Mg}$, both from Aldrich (purity $>98 \%$ ). This material was utilized as support in the preparation of nickel catalyst. For the precursor synthesis, two solutions $0.2 \mathrm{M}$ of metallic alkoxides were prepared using alcohols as solvent. The first solution was prepared dissolving $62.8 \mathrm{~g}$ of aluminum isopropoxide $(0.308 \mathrm{~mol})$ in $1540 \mathrm{~mL}$ of isopropanol and the second one was prepared dissolving $12.56 \mathrm{~g}$ of magnesium ethoxide $(0.110 \mathrm{~mol})$ in $550 \mathrm{~mL}$ of methanol. Both solutions were mixed in a $5 \mathrm{~L}$ beaker then heated to methanol boiling point and under vigorous stirring it was added $330 \mathrm{~mL}$ of water. After adding water, the system was kept under heating and stirring for $3 \mathrm{~h}$ to complete the hydrolysis reaction. The formed material was separated from the alcohols by filtration and further dried in an oven at $120^{\circ} \mathrm{C}$ for $24 \mathrm{~h}$, resulting in a fine powder. This fine powder (mixture of $\mathrm{Mg}$ and $\mathrm{Al}$ hydroxides) was put in a 100 mesh sieve and calcinated in oxidizing atmosphere (air) at the temperatures of $700^{\circ} \mathrm{C}$, for $4 \mathrm{~h}$, to form the spinel phase.

To obtain the $\mathrm{Ni}$ catalyst supported on $\mathrm{MgAl}_{2} \mathrm{O}_{4}$, nickel was impregnated through successive wet impregnations with aqueous solutions of nickel nitrate hexahydrate, where the nominal content of nickel in the catalyst was kept at $20 \%$ (in weight). The impregnation was carried out at $80^{\circ} \mathrm{C}$. Then, samples were dried in an oven for $4 \mathrm{~h}$, followed by calcinations at $700^{\circ} \mathrm{C}$ for $5 \mathrm{~h}$ in air.

\subsection{Catalytic tests}

The decomposition reaction of $\mathrm{CH}_{4}$ was carried out in a quartztube fixed bed flow reactor $(9 \mathrm{~mm}$ i.d.) heated by an electric furnace. Before reactions, the catalysts $(100 \mathrm{mg}$ ) were reduced in situ in an $\mathrm{H}_{2}$ stream at $550^{\circ} \mathrm{C} / 1 \mathrm{~h}$ and $3 \mathrm{~h}$ and $700^{\circ} \mathrm{C} / 1 \mathrm{~h}$ and $3 \mathrm{~h}$, with a heating rate of $10^{\circ} \mathrm{C} \mathrm{min}^{-1}$. The experiments were conducted under atmospheric pressure at $550^{\circ} \mathrm{C}$. The reaction gas was composed of $\mathrm{N}_{2}$ and $\mathrm{CH}_{4}$ at molar ratios of $1: 1 ; 1: 3$; and $7: 1\left(\mathrm{~N}_{2}: \mathrm{CH}_{4}\right)$. The total flow rate of the reaction gas was $80 \mathrm{~mL} \mathrm{~min}^{-1}$. The reactant and the product gases were analyzed with a Shimadzu GC-8A gas chromatograph, equipped with a thermal conductivity detector, a Porapak-Q column and a $5 \mathrm{~A}$ molecular sieve column with $\mathrm{Ar}$ as the carrier gas. The $\mathrm{N}_{2}$ in the reaction gas was used as a diluent and as an internal analysis standard. In this study, the catalytic activity was evaluated in terms of methane conversion.

\subsection{Catalysts characterization}

The X-ray diffraction (XRD) measurements were taken with a PanAnalytical X'pert PRO Multi-Purpose Diffractometer using $\mathrm{Cu} \mathrm{K} \alpha$ radiation $(\lambda=1.5418 \AA$ ) operating at $45 \mathrm{kV}$ and $40 \mathrm{~mA}$. The structural characterization obtained from the XRD data, including the average crystallite size and microstrain determination, were carried out using the GSAS + EXPEGUI program package [22,23], crystallographic information contained in the ICSD database [24] and the Rietveld method. Both the size and microstrain (lattice distortions) of a crystal cause XRD line broadening, and thus the profile function used in this study (number 4 in GSAS + EXPEGUI package) was a convolution of a pseudo-Voigt and asymmetry function, which also uses the microstrain broadening description of Stephens [25]. The XRD pattern line-widths were used to obtain the average size of the crystallites $(L)$ and the microstrain $(\sigma)$ using the formalism shown in Stephens [25], taking into account the instrumental broadening measured with a $\mathrm{Y}_{2} \mathrm{O}_{3}$ standard sample. In each case, background parameters, phase fractions, peak shape

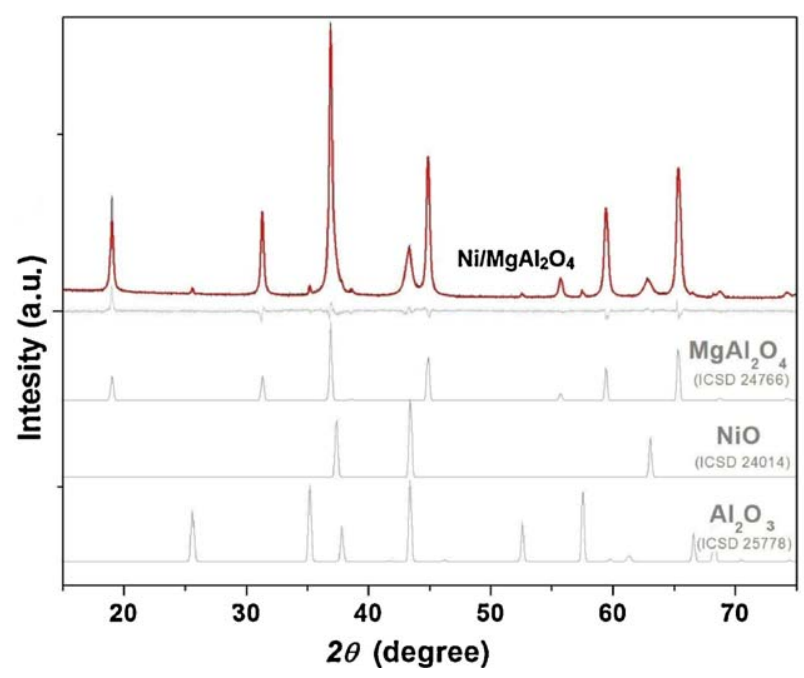

Fig. 1. X-ray diffraction patterns for the $\mathrm{Ni} / \mathrm{MgAl}_{2} \mathrm{O}_{4}$ catalyst. Experimental and calculated (red line) X-ray diffraction patterns for the catalyst. The light gray lines represent the difference between experimental and calculated patterns and dummy patterns of the cubic $\mathrm{MgAl}_{2} \mathrm{O}_{4}$, cubic $\mathrm{NiO}$ and rhombohedral $\mathrm{Al}_{2} \mathrm{O}_{3}$ phases. (For interpretation of the references to color in this figure legend, the reader is referred to the web version of this article.)

parameters, cell parameters and sample position shift were refined before variation of further structural parameters. Isotropic dislocation (thermal) parameters were refined for all the atoms.

Samples were characterized by $\mathrm{N}_{2}$ adsorption/desorption isotherms obtained at the temperature of liquid nitrogen in an automated physisorption instrument (Autosorb-1C, Quantachrome Instruments). Prior to the measurement, the samples were outgassed under vacuum at $200^{\circ} \mathrm{C}$ for $2 \mathrm{~h}$. Specific surface areas were calculated according to the Brunauer-Emmett-Teller(BET) method and the pore size distributions were obtained according to the Barret-Joyner-Halenda (BJH) method.

Temperature-programmed reduction (TPR) analysis was performed to determine the reducible species present at the surface of the catalyst and the temperature at which these species are reduced by $\mathrm{H}_{2}$ consumption. TPR was carried out with Micromeritics Chemisorb 2705 equipment, using $50 \mathrm{mg}$ of catalyst and a temperature ramp from 25 to $1000^{\circ} \mathrm{C}$ at $10^{\circ} \mathrm{C} \mathrm{min}^{-1}$. A $30 \mathrm{~mL} \mathrm{~min}^{-1}$ flow rate of $5 \% \mathrm{H}_{2} / \mathrm{N}_{2}$ was used.

The thermogravimetric analysis (TGA) was carried out in SDT 2960 thermobalance TA Instruments analyzer in Pt crucibles. The analysis was carried out under airflow of $50 \mathrm{~mL} \mathrm{~min}^{-1}$ on heating from room temperature to approximately $900^{\circ} \mathrm{C}$ with a heating rate of $10^{\circ} \mathrm{C} \mathrm{min}-1$ and at the latter it was carried out under airflow of $1.67 \mathrm{~mL} \mathrm{~min}^{-1}$ on heating from room temperature to approximately $900^{\circ} \mathrm{C}$ with a heating rate of $5^{\circ} \mathrm{C} \mathrm{min}^{-1}$.

The morphology of the carbon-containing materials was examined by scanning electron microscopy (SEM) using a Philips XL30 scanning microscope operating at an accelerating voltage of $20 \mathrm{kV}$. Transmission electron microscopy (TEM), with a JEM-1011 microscope operating at an accelerating voltage of $120 \mathrm{kV}$ and Raman spectroscopy obtained on a Raman spectrometer (Renishaw RGH22) with an Ar laser at a wavelength of $514.5 \mathrm{~nm}$.

\section{Results and discussion}

\subsection{Characteristics of $\mathrm{Ni} / \mathrm{MgAl}_{2} \mathrm{O}_{4}$}

Fig. 1 shows the X-ray diffraction (XRD) pattern of the $\mathrm{Ni} / \mathrm{MgAl}_{2} \mathrm{O}_{4}$ sample, the pattern calculated (using the Rietveld method) and three dummy patterns of the cubic $\mathrm{MgAl}_{2} \mathrm{O}_{4}$, cubic 


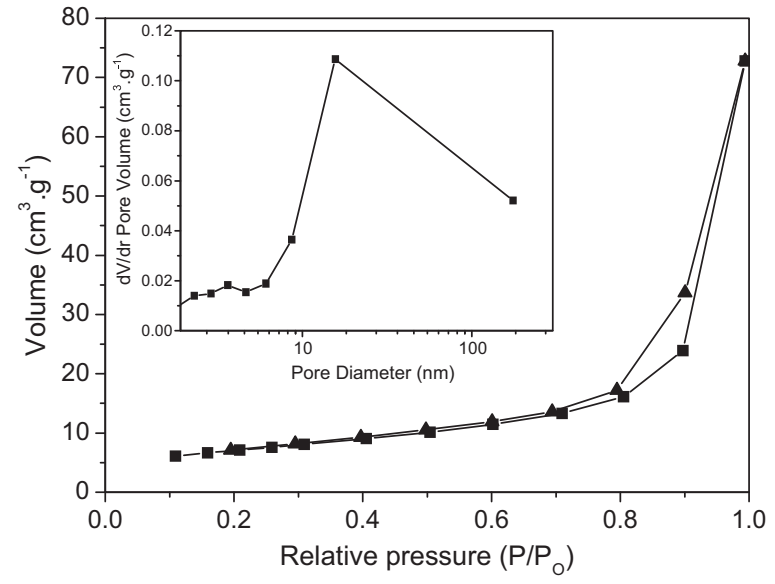

Fig. 2. $\mathrm{N}_{2}$ adsorption/desorption isotherms and pore diameter distribution for the $\mathrm{Ni} / \mathrm{MgAl}_{2} \mathrm{O}_{4}$ sample.

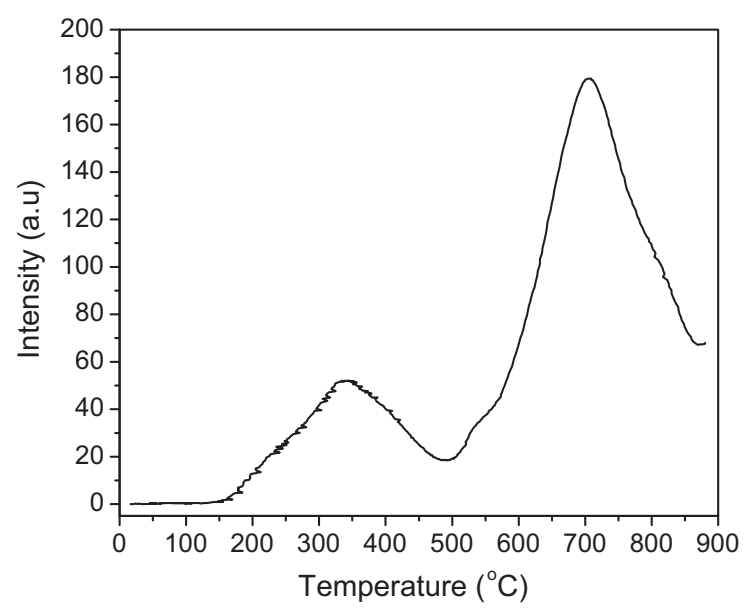

Fig. 3. TPR profile of $\mathrm{Ni} / \mathrm{MgAl}_{2} \mathrm{O}_{4}$ catalyst.

$\mathrm{NiO}$ and rhombohedral $\mathrm{Al}_{2} \mathrm{O}_{3}$ phases. It is important to note that $\mathrm{NiAl}_{2} \mathrm{O}_{4}$ and $\mathrm{MgAl}_{2} \mathrm{O}_{4}$ spinel-like phases are indistinguishable in $\mathrm{XRD}$ analysis. The general $\mathrm{AB}_{2} \mathrm{O}_{4}$ spinel structure consists of $\mathrm{A}^{2+}$ and $\mathrm{B}^{3+}$ ions where the cations can easily displace each other. Therefore, $\mathrm{Mg}^{2+}$ in $\mathrm{MgAl}_{2} \mathrm{O}_{4}$ substitutes $\mathrm{Ni}^{2+}$ upon heat treatment at $700{ }^{\circ} \mathrm{C}$ in oxidizing atmosphere (air). $\mathrm{NiAl}_{2} \mathrm{O}_{4}$ spinel is created during these processes [26,27]. The Rietveld analysis was carried out based on this information and indicated $85 \mathrm{wt} . \%$ of $\mathrm{MgAl}_{2} \mathrm{O}_{4}$ with a lattice parameter $a=8.08035 \AA, 12$ wt.\% of NiO with $a=4.18177 \AA$ and 3 wt.\% of $\mathrm{Al}_{2} \mathrm{O}_{3}$ with $a=4.76217 \AA$ and $c=13.0016 \AA$. The mean crystallite sizes (microstrains) derived from the Rietveld results (peak line widths) were $390 \AA$ (0.4\%) for $\mathrm{MgAl}_{2} \mathrm{O}_{4}, 150 \AA$ (1.0\%) for $\mathrm{NiO}$ and $1400 \AA$ ( $0.3 \%)$ for $\mathrm{Al}_{2} \mathrm{O}_{3}$. The value obtained for the spinel $\mathrm{MgAl}_{2} \mathrm{O}_{4}$ phase agrees with the value of $342 \mathrm{~A}$ for the sample produced from the mixture of aluminum and magnesium hydroxides and calcined at $1100^{\circ} \mathrm{C}[19]$.

Fig. 2 shows the $\mathrm{N}_{2}$ adsorption/desorption isotherms and pore size distribution of the $\mathrm{Ni} / \mathrm{MgAl}_{2} \mathrm{O}_{4}$ sample. The curves presented in Fig. 2 are type-III (IUPAC). This type of isotherm has the characteristics of a system where the adsorbate molecules have a stronger interaction with each other than with the solid [28]. The profile of the pore size distribution (see insert in Fig. 2) indicates the predominance of mesopores. The surface area was $26.2 \mathrm{~m}^{2} \mathrm{~g}^{-1}$ and pore volume of $0.126 \mathrm{~cm}^{3} \mathrm{~g}^{-1}$.

Fig. 3 shows the temperature-programmed reduction (TPR) curve for the $\mathrm{Ni} / \mathrm{MgAl}_{2} \mathrm{O}_{4}$ sample, where two peaks can be observed

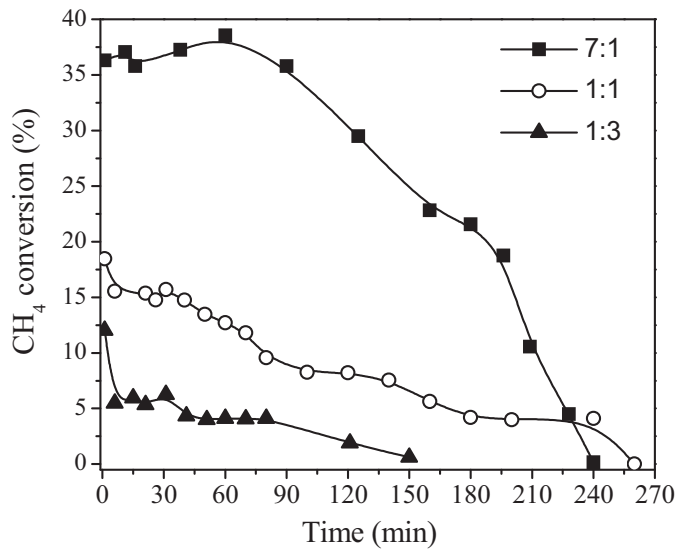

Fig. 4. Methane decomposition over $\mathrm{Ni} / \mathrm{MgAl}_{2} \mathrm{O}_{4}$ catalyst at $550{ }^{\circ} \mathrm{C}$ with different $\mathrm{N}_{2}: \mathrm{CH}_{4}$ molar ratios. Reduction step: $700^{\circ} \mathrm{C} / 1 \mathrm{~h}$.

at around $350^{\circ} \mathrm{C}$ and $700{ }^{\circ} \mathrm{C}$. The first peak can be attributed to $\mathrm{NiO}$ reduction weakly interacted with $\mathrm{MgAl}_{2} \mathrm{O}_{4}$ and the second peak to the reduction of $\mathrm{Ni}$ and $\mathrm{Mg}$ strongly interacted with $\mathrm{MgAl}_{2} \mathrm{O}_{4}$ spinel $[26,29]$, corroborating the XRD results.

\subsection{Methane decomposition over $\mathrm{Ni} / \mathrm{MgAl}_{2} \mathrm{O}_{4}$ catalyst}

In order to investigate the catalytic activity of the $\mathrm{Ni} / \mathrm{MgAl}_{2} \mathrm{O}_{4}$ catalyst, the methane decomposition reaction was carried out. Fig. 4 shows the catalyst behavior with different $\mathrm{N}_{2}: \mathrm{CH}_{4}$ molar rations as a function of the reaction time.

The results showed an increase in the average methane conversion values with an increase in the $\mathrm{N}_{2}: \mathrm{CH}_{4}$ molar ratio. Under a feed flow condition with the methane most diluted the catalyst gave the highest average conversion value (31\%) and the highest initial catalytic activity (37\%). On the other hand, when the methane was very concentrated in the reaction feed flow, that is, using $\mathrm{N}_{2}: \mathrm{CH}_{4}$ in molar ratios of $1: 1$ and $1: 3$, the catalyst gave lower conversion values, not exceeding $18 \%$. This behavior may be due to the amount of active sites present in this catalyst not being sufficient to convert all of the reactive molecules in contact with the catalytic surface because of the increase in the reaction feed flow mixture concentration. Thus, a given amount of reagent would pass through the catalytic bed without undergoing any kind of effective interaction with the catalytic surface, remaining at higher concentrations in the reaction effluent, causing lower methane conversion values. Moreover, in all tests, an ongoing catalytic deactivation until a total loss

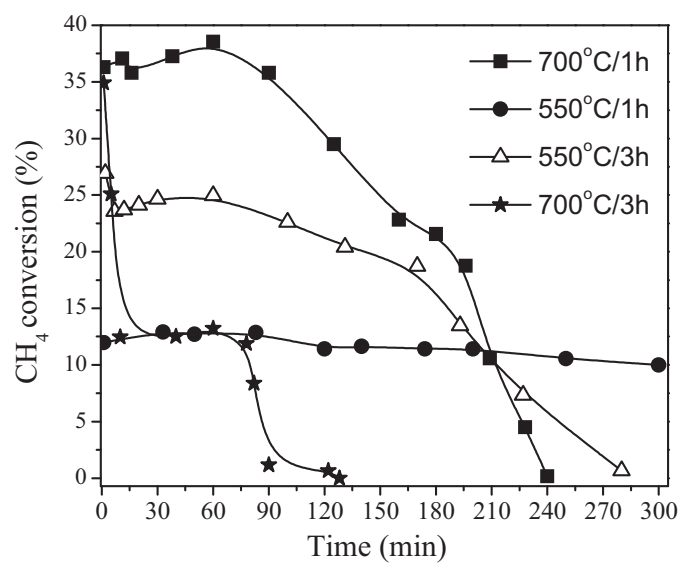

Fig. 5. Methane decomposition over $\mathrm{Ni} / \mathrm{MgAl}_{2} \mathrm{O}_{4}$ catalyst at $550{ }^{\circ} \mathrm{C}$ and $\mathrm{N}_{2}: \mathrm{CH}_{4}$ molar ratio of 7:1, with different conditions of reduction step. 

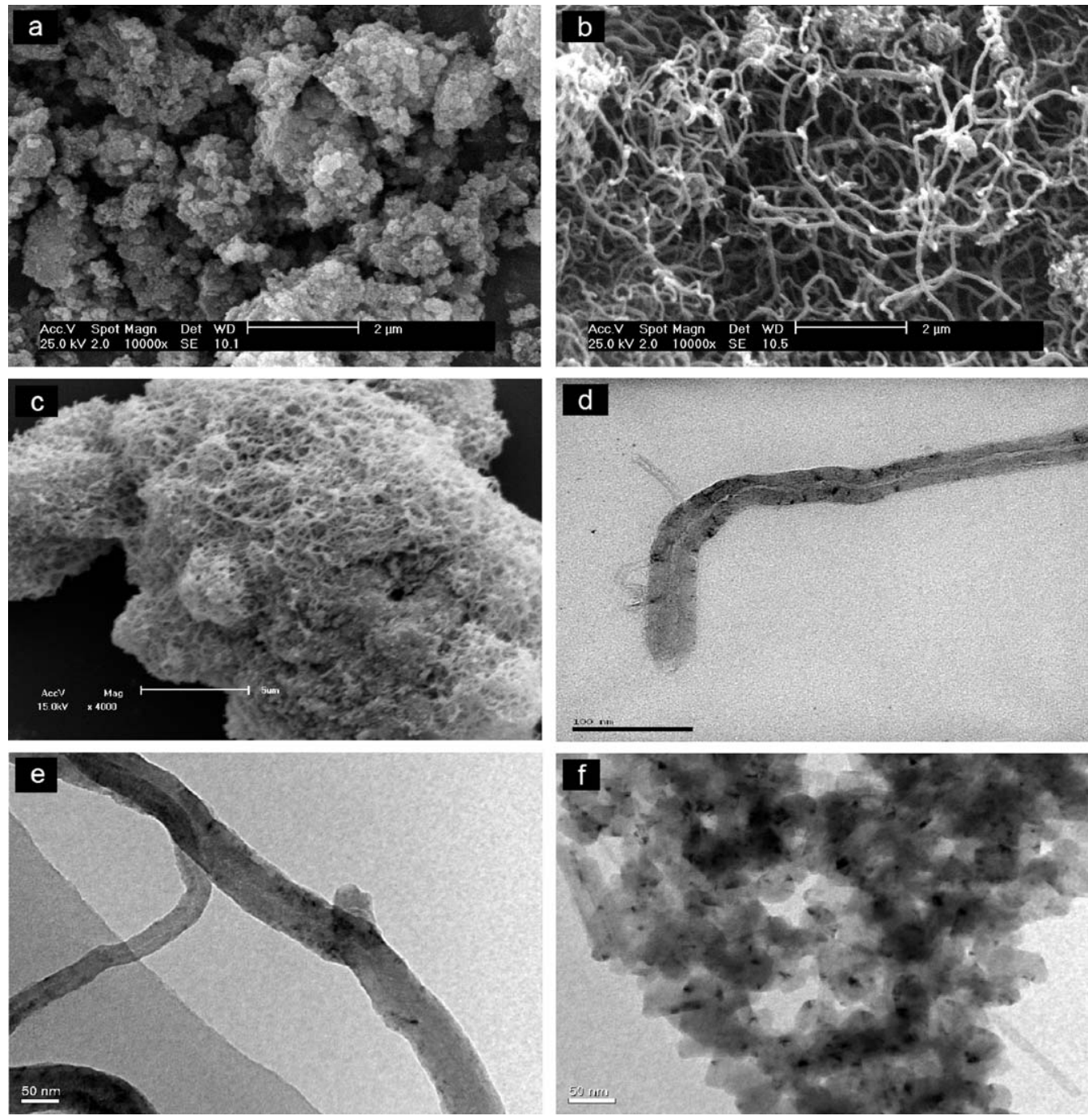

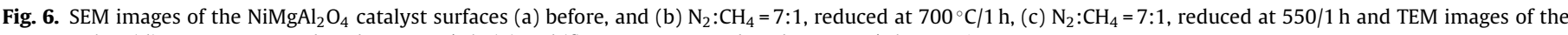
same catalyst (d) $\mathrm{N}_{2}: \mathrm{CH}_{4}=7: 1$, reduced at $700^{\circ} \mathrm{C} / 1 \mathrm{~h}$, (e) and (f) $\mathrm{N}_{2}: \mathrm{CH}_{4}=1: 3$, reduced at $700^{\circ} \mathrm{C} / 1 \mathrm{~h}$. Reaction temperature: $550^{\circ} \mathrm{C}$.

of activity, at 240 min of reaction for a $\mathrm{N}_{2}: \mathrm{CH}_{4}$ molar ratio of $7: 1$, at 260 min of reaction for a $\mathrm{N}_{2}: \mathrm{CH}_{4}$ molar ratio of $1: 1$ and at $150 \mathrm{~min}$ for reaction of a $\mathrm{N}_{2}: \mathrm{CH}_{4}$ molar ratio of $1: 3$, was observed. However, the catalyst with a $\mathrm{N}_{2}: \mathrm{CH}_{4}$ molar ratio of $1: 3$, presented the lowest catalytic activity, not exceeding $12 \%$. This is mainly due to the more extreme working conditions where the formation of carbonaceous materials is favored, giving rise to the surface blocking of the active site [30]. During the catalytic decomposition reaction, methane molecules are initially adsorbed (with dissociative adsorption) and decomposed on the metal surface of the catalyst particle, resulting in the formation of chemisorbed carbon species and the release of gaseous hydrogen; the carbon species then dissolve and diffuse through the bulk of the metal particle. Deactivation occurs when the rate of carbon diffusion through the metal catalyst particle is slower than the rate of carbon formation at the surface of the active metallic sites. Under these circumstances, carbon builds up at the catalyst surface and eventually encapsulates the metal particle causing activity loss [30,31].

Fig. 5 shows the catalytic behavior of the $\mathrm{Ni} / \mathrm{MgAl}_{2} \mathrm{O}_{4}$ catalyst with different reduction temperatures and times as a function of the reaction time.

In all of the tests, catalytic deactivation was observed, except when the catalyst was submitted to the reduction process at $550^{\circ} \mathrm{C} / 1 \mathrm{~h}$. According to the results, it can be observed that the tests carried out with the activated catalyst at $700^{\circ} \mathrm{C} / 1 \mathrm{~h}$ gave higher average values for the $\mathrm{CH}_{4}$ conversion (31\%) and a greater initial catalytic activity (37\%) compared with the catalyst which underwent reduction at $550^{\circ} \mathrm{C} / 1 \mathrm{~h}$ and $550^{\circ} \mathrm{C} / 3 \mathrm{~h}$. The higher reduction temperature may have favored the reduction in reducible species leaving the active phase more available for catalytic activity. The catalyst reduced at $700^{\circ} \mathrm{C} / 3 \mathrm{~h}$ showed a rapid and gradual decrease in catalytic activity, with lower average methane conversion values $(11 \%)$ and shorter reaction time, not exceeding $130 \mathrm{~min}$. This finding may be related to the possibility that this catalyst underwent sintering due to the activation time and temperature, which leads to the active phase being less accessible to the flow of reagent which passes through the reactor bed and thus not converting these regent molecules into carbon and hydrogen products. The catalyst reduced at $550^{\circ} \mathrm{C} / 1 \mathrm{~h}$ presented an average methane conversion of $12 \%$, which remained almost constant until the end of the reaction $(300 \mathrm{~min})$. It is probable that the reduction condition employed was not sufficient for the effective activation of the catalytic sites. The catalyst reduced at $550{ }^{\circ} \mathrm{C} / 3 \mathrm{~h}$ presented initial catalytic activity of around $24 \%$ of the $\mathrm{CH}_{4}$ conversion and total loss of activity at $280 \mathrm{~min}$ of reaction. 
Table 1

Data of mass loss of the $\mathrm{Ni} / \mathrm{MgAl}_{2} \mathrm{O}_{4}$ sample after catalytic decomposition of the methane as a function of the operational conditions.

\begin{tabular}{|c|c|c|c|c|c|}
\hline \multirow[t]{2}{*}{ Entry } & \multicolumn{3}{|c|}{ Operational conditions } & \multicolumn{2}{|l|}{ TGA } \\
\hline & $\mathrm{N}_{2}: \mathrm{CH}_{4}$ & $T_{\mathrm{R}}{ }^{\mathrm{a}}\left({ }^{\circ} \mathrm{C}\right)$ & $T_{\text {Red }}{ }^{\text {a }}\left({ }^{\circ} \mathrm{C}\right) /$ time $(\mathrm{h})$ & Mass loss (\%) & Temperature $\left({ }^{\circ} \mathrm{C}\right)$ \\
\hline 1 & $1: 3$ & 550 & $700 / 1$ & 66 & 625 \\
\hline 2 & $1: 1$ & 550 & $700 / 1$ & 86 & 586 \\
\hline 3 & $7: 1$ & 550 & $700 / 1$ & $3-66$ & $250-600$ \\
\hline 4 & $7: 1$ & 550 & $700 / 3$ & 4 & 546 \\
\hline 5 & $7: 1$ & 550 & $550 / 1$ & 55 & 625 \\
\hline 6 & $7: 1$ & 550 & $550 / 3$ & 79 & 607 \\
\hline
\end{tabular}

a $T_{\mathrm{R}}$, reaction temperature; $T_{\text {Red }}$, reduction temperature.

\subsection{Characterization of deposited carbons}

TGA is a very powerful technique for determining the quality of the synthesized CNTs due to differences in oxidation stability and degree of graphitization. It appears that various types of carbon such as amorphous carbon and CNT possess different oxidation temperatures and can be distinguished using the TGA technique [32]. Results of mass loss determined from the thermogravimetric curves (not shown here) of the $\mathrm{Ni} / \mathrm{MgAl}_{2} \mathrm{O}_{4}$ catalyst after the catalytic tests under all operational conditions studied in this work are shown in Table 1.

The thermogravimetric analysis of the $\mathrm{Ni} / \mathrm{MgAl}_{2} \mathrm{O}_{4}$ catalyst after the catalytic tests at $550^{\circ} \mathrm{C}$ showed a mass loss in the region of $546-625^{\circ} \mathrm{C}$. It can be observed for entries $1,3,5$ and 6 that there was a mass loss of $66 \%$ at $625^{\circ} \mathrm{C}$ and $600{ }^{\circ} \mathrm{C}, 55 \%$ at $625^{\circ} \mathrm{C}$ and $79 \%$ at $607^{\circ} \mathrm{C}$, respectively. The mass loss of this material at above $600^{\circ} \mathrm{C}$ can be attributed to the MWNTs [31,33]. It can also be noted from entry 3 that there was a mass loss of $3 \%$ at $250{ }^{\circ} \mathrm{C}$, which can be attributed to amorphous carbon which decomposes at temperatures below this value. In the case of entries 2 and 4, there was a mass loss of $86 \%$ at $586^{\circ} \mathrm{C}$ and $4 \%$ at $546^{\circ} \mathrm{C}$. This may be associated with small amounts of amorphous particles in the nanotubes, the influence of metal particles and/or defects on the surface of the nanotubes. These factors can affect the temperature at which the maximum decomposition rate occurs. It can be concluded that in any of the operational conditions employed, the formation of material more steady as the CNTs occurs [34-37].

The SEM and TEM characterizations of the carbon-containing materials after the $\mathrm{CH}_{4}$ reaction are shown in Fig. 6. The SEM image presented in Fig. 6a shows the $\mathrm{Ni} / \mathrm{MgAl}_{2} \mathrm{O}_{4}$ sample before of the catalyst tests. The images obtained in the SEM (Fig. 6b and c) and TEM (Fig. 6d-f) analyses show that after the catalytic tests there were modifications on the catalyst surface due to the deposition of carbonaceous material. These images suggest that different carbon species were formed according to the feed flow of the reaction and variations in the reduction temperature and time, with a significant formation of CNTs. The formation of carbon nanotubes with a diameter of approximately $40 \mathrm{~nm}$ can be clearly observed in Fig. 6d. It was identified that besides the deposition of carbon in the form of CNTs there was the presence of fibers and irregular agglomerations, as observed in Fig. 6e and f, respectively. The results show that there was the preferential formation of carbon nanotubes in the case of the $\mathrm{Ni} / \mathrm{MgAl}_{2} \mathrm{O}_{4}$ catalyst in the decomposition reaction with higher molar ratios $\left(\mathrm{N}_{2}: \mathrm{CH}_{4}=7: 1\right)$. This result may explain, or at least be related to, the greater stability of the catalyst under this experimental condition. For the catalyst in the decomposition reaction with lower molar ratios $\left(\mathrm{N}_{2}: \mathrm{CH}_{4}=1: 3\right)$, besides the nanotubes, the formation of carbon agglomerations and nanofibers was identified, which may favor catalytic deactivation. The images in Fig. $6 \mathrm{~d}-\mathrm{f}$ show some black points which may be attributed to the nanoparticles of $\mathrm{Ni}$ and/or amorphous carbon, which were involved and deposited on the walls of carbon nanotubes. Similar behavior has been described by Hsieh et al. [38], Zhou et al. [39] and Guevara et al. [40], employing metal and bimetal catalysts of Pt, Pt-Ni(Fe, Co) and $\mathrm{Ni}-\mathrm{Ce}$, respectively.

\section{Conclusions}

The results indicated that the $\mathrm{Ni} / \mathrm{MgAl}_{2} \mathrm{O}_{4}$ sample is composed by nanometric crystallites of $\mathrm{MgAl}_{2} \mathrm{O}_{4}$ spinel phase ( $85 \mathrm{wt} . \%$ ), $\mathrm{NiO}$ phase (12 wt.\%) and $\mathrm{Al}_{2} \mathrm{O}_{3}$ (3wt.\%). It was observed that the catalytic performance, activity and stability, are dependent on the operational conditions employed. According to the results, the best conditions for methane decomposition were $\mathrm{N}_{2}: \mathrm{CH}_{4}$ molar ratio of $7: 1$ and reduced temperature of $700^{\circ} \mathrm{C} / 1 \mathrm{~h}$, at reaction temperature of $550{ }^{\circ} \mathrm{C}$. The results here obtained also show that the $\mathrm{Ni} / \mathrm{MgAl}_{2} \mathrm{O}_{4}$ catalyst is effective for the production of carbon nanotubes.

\section{Acknowledgments}

The authors are grateful to Federal University of Santa Catarina (UFSC) for infrastructure (including LCME, LDRX and LabMat facilities), and CNPq (Brazil) for financial support.

\section{References}

[1] T.V. Choudhary, C. Sivadinarayana, A. Chusuei, A. Klinghoffer, D.W. Goodman, J. Catal. 199 (2001) 9-18.

[2] N. Muradov, Z. Chen, F. Smith, Int. J. Hydrogen Energy 30 (2005) 1149-1158.

[3] N.Z. Muradov, Energy Fuels 12 (1998) 41-48.

[4] J.L. Pinilla, I. Suelves, R. Utrilla, M.E. Gálvez, M.J. Lázaro, R. Moliner, J. Power Sources 169 (2007) 103-109.

[5] J.L. Pinilla, I. Suelves, M.J. Lázaro, R. Moliner, J.M. Palacios, Int. J. Hydrogen Energy 35 (2010) 9801-9809.

[6] K. Otsuka, S. Kobayashi, S. Takenaka, Appl. Catal. A: Gen. 190 (2000) 261-268.

[7] J. Chen, Y. Qiao, Y. Li, Appl. Catal. A: Gen. 337 (2008) 148-154.

[8] J. Ashok, S.N. Kumar, A. Venugopal, V.D. Kumari, M. Subrahmanyam, J. Power Sources 164 (2007) 809-814.

[9] S.K. Saraswat, S.S Pant, Int. J. Hydrogen Energy 36 (2011) 13352-13360.

[10] I. Suelves, J.L. Pinilla, M.J. Lázaro, J.M. Palacios, J. Power Sources 192 (2009) 35-42.

[11] J. Ashok, G. Raju, P.S. Reddy, M. Subrahmanyam, A. Venugopal, Int. J. Hydrogen Energy 33 (2008) 4809-4818.

[12] M.E. Rivas, C.E. Hori, J.L.G. Fierro, M.R. Goldwasser, A.G. Constant, J. Power Sources 184 (2008) 265-275.

[13] S. Takenaka, H. Ogihara, I. Yamanaka, K. Otsuka, Appl. Catal. A 217 (2001) 101-110.

[14] W. Kim, F. Saito, Powder Technol. 113 (2000) 109-113.

[15] J.G. Li, T. Ikegami, J.H. Lee, T. Mori, Y. Yajima, Ceram. Int. 27 (2001) 481-489.

[16] L.R. Ping, A.M. Azad, T.W. Dung, Mater. Res. Bull. 36 (2001) 1417-1430.

[17] A.D. Mazzoni, M.A.Sainz, A. Caballero, E.F Aglietti, Mater. Chem. Phys. 78 (2003) 30-37.

[18] A.S. Bocanegra, A.D. Ballarini, O.A. Scelza, S.R. Miguel, Mater. Chem. Phys. 111 (2008) 534-541.

[19] E. Foletto, R.W. Alves, S.L. Jahn, J. Power Sources 161 (2006) 531-534

[20] J. Guo, H. Lou, H. Zhao, D. Chai, X. Zheng, Appl. Catal. A: Gen. 273 (2004) 75-82.

[21] G.D.B. Nuernberg, H.V. Fajardo, E.L. Foletto, S.M.H. Probst, N.L.V. Carreño, L.F.D. Probst, J. Barrault, J. Catal. Today 176 (2011) 465-469.

[22] A.C. Larson, R.B.V. Dreele, Los Alamos National Laboratory Report LAUR 86-748, 2004.

[23] B.H. Toby, J. Appl. Cryst. 34 (2001) 210-213.

[24] Inorganic Crystal Structure Database (ICSD), Gmelin-Institut für Anorganische Chemie and Fachinformationszentrum, FIZ, Karlsruhe, 2007.

[25] P.W. Stephens, Appl. Cryst. 21 (1999) 281-289.

[26] D.S. Park, Z. Li, H. Devianto, H. Lee, Int. J. Hydrogen Energy 35 (2010) 5673-5680. 
[27] A. Monzón, N. Latorre, T. Ubieto, C. Royo, E. Romeo, J.I. Villacampa, L. Dussault, J.C. Dupin, C. Guimon, M. Montioux, Catal. Today 116 (2006) 264-270.

[28] V.G. Teixeira, F.M.B. Coutinho, A.S. Gomes, Quím. Nova 24 (2001) 808-818.

[29] H. Ozdemir, M.A.F. Oksuzomer, M.A. Gurkaynak, Int. J. Hydrogen Energy 35 (2010) 12147-12160.

[30] G.B. Nuernberg, H.V. Fajardo, D.Z. Mezalira, T.J. Casarin, L.F.D. Probst, N.L.V. Carreño, Fuel 87 (2008) 1698-1704.

[31] R.M. Almeida, H.V. Fajardo, D.Z. Mezalira, G.B. Nuernberg, L.K. Noda, L.F.D. Probst, N.L.V. Carreño, J. Mol. Catal. A: Chem. 259 (2006) 328-335.

[32] C.M. Chen, Y.M. Dai, J.G. Huang, J.M. Jehng, Carbon 44 (2006) 1808-1820.

[33] G.S. Gallego, J. Barrault, C.B. Dupeyrat, F. Mondragón, Catal. Today 149 (2010) 365-371.
[34] A.B. Suriani, A.A. Azira, S.F. Nik, R.M. Nor, M. Rusop, Mater. Lett. 63 (2009) 2704-2706.

[35] N. Das, A. Dalai, J.S.S. Mohammadzadeh, J. Adjaye, Carbon 44 (2006) 2236-2245.

[36] E. Maccallini, T. Tsoufis, A. Policicchio, S.L. Rosa, T. Caruso, G. Chiarello, E. Colavita, V. Formoso, D. Gournis, R.G. Agostino, Carbon 48 (2010) 3434-3445.

[37] P.Z. Poor, A. Badiei, A.A. Yousefi, B.D. Fahlman, A. Abbasi, Catal. Today $150(2010)$ $100-106$.

[38] C. Hsieh, J. Lin, J. Wei, Int. J. Hydrogen Energy 34 (2009) 685-693.

[39] M. Zhou, G. Lin, H. Zhang, Chin. J. Catal. 28 (2007) 210-216.

[40] J.C. Guevara, J.A. Wang, L.F. Chen, M.A. Valenzuela, P. Salas, A. García-Ruiz, J.A. Toledo, M.A. Cortes-Jácome, C. Angeles-Chavez, O. Novaro, Int. J. Hydrogen Energy 35 (2010) 3509-3521. 